\title{
The Inspiration Given by the Successful Practice of Development of Higher Vocational Education in the Developed Countries
}

\author{
Gaoling $\mathrm{Wu}$ \\ Huazhong University of Science and Technology, \\ Academy of Educational Sciences, China Wuhan 430074 \\ E-mail: xhw@zjnu.cn
}

\begin{abstract}
Higher vocational education is the product of economic development, scientific and technological progress. If the country does not have a well-developed vocational education, it is impossible to make a good advanced science and technology into productive forces, it is also impossible to achieve economy development in a high speed. In turn, powers the global economy, there must be a successful higher vocational education as a support .Study on the successful experience of the development of higher vocational education in the United States, Japan, Germany, Australia and other developed countries can give us useful lessons.
\end{abstract}

Keywords: Developed Countries, Higher Vocational Education, Inspiration

\section{Introduction}

From the end of the last century to the beginning of this century, the United States, Japan, and Germany have been ranked the world's top three economic powers. Especially the United States is not only a major economic power, but also science and technology, education, etc. superpower. Just a few decades, Japan and Germany, defeated fellow in World War II, have become the forefront of the world's economic power. In recent years, Australia has also made the world afresh with heritage of pride in the field of higher vocational education. Stones from other hills may serve to polish jade. What are features of higher vocational education in these Western developed countries? What are the success stories? What are the implications for us? In Western developed countries, higher vocational education development is of great significance to China's higher vocational education.

Higher vocational education is the product of economic development, scientific and technological progress. A country has only developed general education but not well-developed vocational education, it is impossible to make advanced science and technology well into productive forces, it is also impossible to make the fast economy development. In turn, powers the global economy, there must be a successful higher vocational education as a support.

Below is a brief introduction of advanced Western economic powers higher vocational education sessions.

\subsection{Higher Vocational Education in the United States}

Vocational and technical education system in the United States, was founded in the beginning of the last century, formed a nationwide general vocational and technical education system in the 60's. One of them was recognized as the most successful is the community colleges (Community college), it aims at serving the community, sets university education, vocational education and adult education together; Community colleges can be said to be a major undertaking in American higher education.And in the eyes of the world, community college is considered as the unique contribution made by United States in the field of higher education.

The creation of U.S. community colleges can be traced back to the activities of the Junior College (Junior college movement) in the late 19th century and early 20th century. University of Chicago president (W $\bullet$ R $\bullet$ Harper) established the first two-year junior college in 1892. Community college educational goals primarily for transporting high school students into undergraduate institutions did not form its own characteristics in the initial stage. The need for higher education became more urgent with America's economic output surge after World War II. Especially the millions of veterans facing pre-employment training, for that Congress passed the "Veterans Employment Law", the bill funding 2 million veterans to college. With the social and economic development, community colleges transformed its functions rapidly, shifting from transferring education to vocational and technical personal training which is much-needed by regional economic development.

The 20th century, 80 years, as the "third" industrial revolution, the U.S. economy is in a turning point. After President Reagan took office, he proposed "economic recovery plan." It was the need to adapt to the new technological revolution and maintain U.S. economic supremacy; the U.S. introduced the "Vocational Training Cooperation Act" in 1982.

Most of the public community college offers three kinds of services. First, Careers Education. For the purpose of 
continuing their studies in university after graduating, this part of students accounted for about $30 \%$. Second, Occupations (subsistence) Education. Students for the purpose of obtaining a credentials and employment through vocational training, accounting for about 50\%. Third, the Community Service. Including adult continuing education and business training and retraining programs, students for the purpose of updating their knowledge and enriching rising, accounting for about 20\%. NOW United States has 1200 Community Colleges, more than 1000 million students studying in each year. Community college students accounted for $44 \%$ of the total number of American college students, freshman accounting for $50 \%$ of the total number of American university students.

\subsection{Higher Vocational Education in Japan}

There are many higher vocational education institutions in Japan. From the perspective of industry and occupation, higher specialized schools, including vocational ability development's university which belongs to Ministry of Labor, mainly meet need of the secondary sector services, recruiting male in large measure. While the Junior College, mainly meet need of the tertiary-industry, recruiting female in large measure. Before World War II, the form of vocational education is "Industrial Education" in Japan. After the Second World War, the form of vocational education is mainly as "industrial education." Taking the U.S. education system as a model, Japan formed "6334" system in the postwar. Based on the concept of democratization of education, equal opportunities in education, it carried out some reform of the University of Unitary higher education. It did not set up specifically schools only have the university in the field of higher education. As the needs of social development, the Junior College was approved to be established in 1950 (one year later than the new system of the University). In 1952, The Japan Business Federation which is on behalf of Japanese business managers (Referred to as Japan's Nikkei Alliance) put forward that "the new requirements of further discussion on the education system," and vehemently criticized the new university system. Nikkei Union further proposed "On the current educational reform requirements", "Make the University have their own focus and characteristics in academic research, vocational special education, teacher training etc. Abolition of a national uniform ", shorten part of the new system the University's fixed number of years, or by integrating some short-term universities and vocational high schools, establishing five-year junior college career."

The first batch of 12 the National College of Technology were established in 1962. Short-term university system achieved the permanency in 1964, Japan College of Technology had reached 54 in 1965, it basically has remained stable at around 64 since1970. Specialist Schools' institution was introduced in 1975, "Specialist Schools Act," was born in 1976, the benchmark for setting Specialist Schools was published. Then there were 893 different types of schools converted or upgraded to Specialized Schools. The number of Specialist Schools soared to 1941 in the following year, the number of Japan Specialist Schools had reached 3441 by 2006, 213,000 high school graduates were enrolled, the number of students up to 75 million. Its scale was far beyond Junior College and National College of Technology.

\subsection{Higher Vocational Education in Germany}

Germany has embarked vocational training for a long history, as early as the 13th century, there were training in the form of "masters train an apprentice". After industrialization replacing the craft and the guild system in 19th century, then "Industrial Code" has made explicit stipulations on vocational education. The implementation of higher vocational education institutions were mainly by Fachhoch schule, and Berufs a kademie in Germany. German states reached agreement on the establishment of Specialist University in 1968, the federal government passed the "Vocational Education Law" in August, 1969; Under the agreement, from 1969 to 1971, the original Federal French engineer school (three years), college and Senior College of Industrial Design, social welfare class school, High-Level Economic College were rebuild into Specialist university to meet higher demands of Professional Talent made by the scientific, technological progress. Vocational College is a higher vocational education institutions which is Germany typical "dual system" model, is as another type of higher education in addition to universities, specialized non-university.

\subsection{Higher Vocational Education in Australia}

The development of vocational education in Australia can be divided into three stages after World War II. The first phase is of the start-up from 20th century $50 \mathrm{~s}$ to $70 \mathrm{~s}$, the second phase is of adjustment and reform from the 20th century, 70 years to 90 years, the third is the formative stages of system since the 20th century 90s. Australia's vocational and technical education and training well received by the world's attention in recent years; in particular the TAFE system of vocational education which was created at the age of 70. TAFE is the abbreviated as "Technical and Further Education", TAFE is an important pillar of Australia's vocational education system. It is a high-quality education and training system which is under the framework of a nation, as an industry driving force and customer-centric, limberly running schools, with an effective interface between secondary schools and universities.

The above-mentioned countries have a set of vocational education system (model) suited to their national conditions. China's development paths of Higher Vocational Education only rely on our own to explore. But "stones from other hills may serve to polish jade", higher vocational and technical education system in advanced countries, was developed 
with the process of industrialization. Their success is worth of learning and emulating.

\section{Carry out Open Learning and effectively improve vocational education's function which service the regional economy and society}

America's Community College has been able to be eternity for more than a century, and the fundamental reason is that she was to integrate itself into the community providing a full range of education and training services for the community's residents, businesses and employees. Yet many local governments in our country take higher vocational colleges as a "financial" burden, keen on GDP and industry's promotion, put inadequate attention on the skilled expertise. As a vocational institution, is not out of the traditional "ivory tower", habitually engaged in a quasi-elite teaching. The school policy "for the purpose of service" only remains in the slogans, the purpose of service for area economic and social development is overlooked frequently. What is more, this purpose is left side remotely. They know little of Local government's economic and social development, and do not have any reaction to the regional industrial structure adjustment; they even know nothing about Key pillar industries and enterprises in the region. Some of Vocational-Technical leadership aren't aware of taking the initiative to serve on regional economic and social development, while others who have this consciousness, not willing to do or do not know how to do. The resulting situation is this: On the one hand, the economic and social development needs of a large number of highly skilled personnel. On the other hand, a large number of graduates from higher vocational institutions have difficulty in employment every year.

From the government's view, the number of China's vocational schools has reached 1200 currently, achieving the goal of each prefecture-level cities at least have one Vocational Colleges basically, but this is only the first step. Local government should bring Vocational Colleges into the overall planning of local economic development; making Vocational Colleges act as the base of training and producing regional economic high-skilled personnel and reserve labor force. The vocational college must make the most of the advantage in their human resources, science and technology information resources, and other areas, take the initiative to serve the local regional economy and social development, provide information consultation for the Government and technology services for enterprises, and offer the best possible educational and vocational training services to the region. Deeply into factories, workshops and field, turndown, provide services for the front-line workers and farmers. Therefore, Vocational Colleges should keep in mind the school policy "for the purpose of service ", ascertain their own service targets, make the vocational colleges socially oriented. In particular, be a center of regional economic and social, open, multi-vocational education and training, providing a full range of services for the region's students, businesses, employees.

\section{Meet the dual needs of the industry and further education, conscientiously do a good job of employment and recruitment markets}

Japan, as the world's second largest economic aggregate among the developed countries, is known as one of the most successful countries in vocational education market. The key lies in its better suited to the dual needs of industry and further education, and its implementation of the Japanese Vocational Education marketization and diversification. In the whole higher education, Japan takes a suppressive policy to blind expansion of higher academic, while expands and gives guide policy to vocational education. The development of Junior College and Specialist Schools, which are greatly needed, is determined by the market, for the development of industries, especially the manufacturing which is the post-war Japan's base industry, the Government set up National College of Technology and Vocational Ability Development University. Take Specialized Training College for example, Japan jointly set up 893 in 1976, covering almost every job in society. and more than $93 \%$ of these schools are private, the government made two major events, first, checking the condition of setting schools and approval the standard ,second, set the scale and standard quota of staff in accordance with conditions.

\section{Intensify education and teaching reform and innovation, and carry out the combining work and study personnel training mode}

On earth, how to conduct China's Higher Vocational Education Reform Innovation? Practice has proved that "compression of the undergraduate" is unworkable. Two issues involved here: First, what to teach, and second, how to teach. Australia's TAFE system gives us a useful inspiration. I think that the core of China's higher vocational education building and reform is to exploit and develop the "training package" in line with China's national conditions and industry, enterprise features, abandoning the traditional "syllogism" teaching mode as soon as possible. "training package" should be formulated by government rather than school taking the lead. According to industry standards and professional positions (group) requirements, organizing labor departments, industries, enterprises, including schools, and other relevant departments to develop the "training package." so as to solve the problem of what to teach.

With regard to "how to teach", the success of German "dual system" is that the students learn and practice variety of professional job-related skill in a real enterprise environment. In China, except for few in our industry, enterprise-run vocational schools have this condition, it is very difficult to do this to the majority of schools. However, we must 
actively promote and implement the learning pattern which combines labor and social practice, emphasis on consistency of students' campus learning and practical work, take " the combining work and study " as higher vocational basic personnel training mode. Extensively carrying out a variety of teaching mode like working and learning alternation task-driven, project-oriented, Ding Gang internships and so on, melting of "teaching, learning, doing" was one. Trying to make students to master the technology and skills "physically", adopting a variety of effective measures to enhance the students hands-on ability and practical operation abilities.

\section{Establish the concept of lifelong education, and build a modern vocational education system for everyone}

America's Community College are flourishing long time. One of the key reasons is its introduction of lifelong education for all. Less than $4 \%$ of high school graduates and vocational graduates, can be further studies, yet the majority can not receive continue studies in our country. The state has identified that Vocational Education is a type of higher education currently, but it is only specialist level, with the economic development and technological advances, it may offer undergraduate or graduate level of higher vocational education. At the same time vocational education and general education should communicate and coordinate with each other. On the other hand, now vocational colleges are almost engaged in full-time academic education, it should widely carry out variety of training in the future. Providing a full range of education and training services for the transfer of migrant workers, laid-off workers, reorientation and re-employment training.

\section{System design for the structure of vocational education}

China's higher vocational education is the result of economic development of a certain stage, objectively socio-economic diversity requires the diversification of types of vocational schools. The types and levels of vocational dispute seem to have a clear answer after the introduction of high-paper No. 16 since 2006. In fact, the country has not a clear-cut policies and measures on the entire system design for the structure of higher vocational education system. As we all know, the existing system of vocational education system is based on "level" to design, vocational colleges only have one level- vocational school. New students are the last batch of college entrance examination in terms of admission. These are reasons for that vocational colleges' attraction is not strong, and barriers which constrain the further development of vocational colleges. The file of education department has confirmed that higher vocational education is just a type of education, it is only the type of distinction between vocational and general higher education. There is no ranking point. Higher vocational education may do undergraduate or graduate education in needs of economic and social development.

All in all, China's vocational education has made a historic breakthrough development with 30 years of reform and opening up. China's higher vocational education reform is at a critical period at present. Finding out the characteristics of vocational education in developed countries, drawing lessons from their successful experience, and extracting the lessons of others, can help new higher vocational education effectively avoid the detours, give great positive significance to the sustainable ,healthy and scientific development of China's higher vocational education.

\section{References}

Liu, Fujun, Chen, Wenzhang. (2007). Higher Vocational Education Training Mode. Beijing: Science Press.

Zuo Yanpeng. (2003). The experience and development of American Community College. China's Vocational and Technical Education, (4):56-58.

Hu, Guoyong. (2008). literature. Shanghai: Shanghai Education Publishing House, (6). Japanese Higher Vocational Education Research

Jiang Dayuan. (2004). Briefing of German institutions of higher learning. China's vocational and technical education, (20):56-58.

He, Zhanbin. (2007). The enlightenments and comparison of Australia's TAFE system and China's vocational education and. China's power of education, (7):52-54. 